\title{
AN ANALYSIST OF SA'ADUDIN DJAMBEK'S HISAB METHOD ABOUT ALL THE TIME OF PRAYING SCHEDULE
}

\author{
Nailur Rahmi', Firdaus ${ }^{2}$ \\ ${ }^{1}$ Institut Agama Islam Negeri Batusangkar, ${ }^{2}$ Institut Agama Islam Negeri Batusangkar \\ innelzena02@gmail.com, ${ }^{2}$ almuqaddasfirdaus@gmail.com
}

\begin{abstract}
The development of Islamic Astronomy (Falak) inevitably influenced by previous Falak scholars, like Sa'aduddin Djambek which popular with his book "Pedoman Waktu Shalat Sepanjang Masa (The guidance about all the time of praying schedule)". Currently, the book still refferenced as the praying schedule determination in some areas in West Sumatra. The main issues of this research are to answer abot how the hisab method of all the time of praying schedule by Sa'aduddin Djambek as well as how to analyze this method. Then, the objectives of the research is to describe the calculation method of all the time praying schedule and analyze this method. The result shows that the determination of the beginning of praying schedule in Indonesia it mostly close or even equal to the result of modern hisab. Some factors causes the diffences of hisab result is method, formula, and data. Nevertheless, the differences are not that much, it is only 1 to 2 minutes. Besides, the all time praying schedule sometimes sooner and later than hisab result of praying schedule calculated by contemporary hisab method. Therefore, it can be assumed that the all time praying schedule is accurat hisab method, since its result close or even equal to contemporary hisab method. Moreover, its calculation is more simple and understandable.
\end{abstract}

Keywords: Sa'aduddin Djambek's Hisab, Praying Schedule, All the Time

\section{Abstrak}

Perkembangan ilmu Falak saat ini tidak terlepas dari keterlibatan ahli falak sebelumnya, seperti Sa'aduddin Djambek yang terkenal dengan karyanya "Pedoman Waktu Shalat Sepanjang Masa". Sampai saat ini kitab tersebut masih menjadi rujukan dalam penentuan awal waktu shalat di beberapa wilayah di Sumatera Barat. Pokok permasalahan dalam makalah ini adalah bagaimana metode hisab awal waktu shalat sepanjang masa menurut Sa'aduddin Djambek dan bagaimana analisis terhadap metode hisab waktu shalat sepanjang masa. Adapun tujuan dari penulisan ini adalah untuk mendiskripsikan hisab awal waktu shalat sepanjang masa dan menganalisis 
metode hisab awal waktu shalat sepanjang masa. Analisis yang diperoleh dari metode Hisab tersebut, bahwa dalam penetapan awal waktu shalat wajib untuk wilayah Indonesia, jadwal waktu shalat sepanjang masa banyak yang mendekati bahkan ada yang sama dengan hisab kekinian. Faktor-faktor yang menyebabkan terjadinya perbedaan hasil hisab tersebut karena disebabkan oleh cara-cara, rumus dan data yang digunakan. Walaupun demikian, perbedaan-perbedaan hasil yang didapatkan tidak mencapai pada takaran waktu yang cukup jauh, tapi hanya terpaut pada menit saja dengan selisih antara 1-2 menit. Selain itu jadwal shalat sepanjang masa kadang lebih awal dan kadang lebih akhir daripada jadwal shalat hasil perhitungan dengan rumus hisab kontemporer. Sehingga dengan demikian dapatlah dikatakan bahwa metode hisab waktu shalat sepanjang masa merupakan metode hisab yang akurat dan hasil hisab mendekati hasil yang sama.dengan hisab kekinian. Selain itu proses perhitungannya lebih sederhana dan mudah dipahami.

Kata kunci: Hisab Sa'aduddin Djambek, Waktu Shalat, Sepanjang Masa

\section{A. Introduction}

The implementation of Islamic law inevitably separated from space, direction, and time which strongly influence the development of basic Falak science. For example, the command for rukyah hilal in the end of the Hijri month as a sign to determine the new Hijri month. In the Past, prophet Muhammad actually used hisab to support rukyah. In order to do rukyah before Ramadhan, he has to know when the 29th date of Sya'ban. (Moh. Murtadho, 2008: 21)

Similiar to Hijri month commencement, the obligation of shalat on time as well as wukuf and idul adha also need calculation/hisab. Although determination of praying schedule part of Falak discussion, but historically Falak was less scientific during the early Islam era and unpopular among moslem society. In Indonesian Islamic history, Karel A. Steenbrik argued that Falak was specifically divided into two periods namely the period of Islamic propagation to Indonesia and reformism period in $20^{\text {th }}$ century. (Slamet Hambali, 2011: 17)

Some Falak books which developed in Indonesia mostly referred from Egyptian scholars, namely "al-Mathla' al-Said ala Rasdi al-Jadid". The development of Falak knowledge in Indonesia was inevitably influenced by Islamic scholar's network, such as "Khunlashah al-Wafiayah" written by Umar al-Jailany, "Hisab Hakiki" written by K. Wardan Diponingrat, "Badiah al-Mitsal" written by Ma'shum Jombang, and "Almanak 
Menara Kudus" written by Turaikhan Ajhuri are books which referred from "Matha' alSaid ala Rasdi al-Jadid”. (Moh. Murtadho, 2008: 36)

\section{B. Method}

The current development of Falak influenced by previous Falak scholars such as Sa'aduddin Djambek which popular with his research namely "Pedoman Waktu Shalat Sepanjang Masa (the Guidance of All the Time Praying Schedule)". The book still becomes the main referrence in determining the begining of shalat time in some areas in West Sumatra. Therefore, author interested to scrutinize the hisab of the begining of all the time shalat schedule which discussed on that book. This research is library research. Author wil describe a methode used by Sa'aduddin Djambek to hisab prayer time and then analize it.

\section{Discussion and Result}

\section{Hisab the Beginning of Shalat Schedule}

a. Definition of Shalat

Ephistimologically, Shalat means praying. Then, according to its terminology shalat means worship which contains with specific words and actions that started by takbir and ended by salam. (Sayyid Sabiq, 2008: 158)

b. The legal basis of the determination of the beginning of shalat schedule, that is:

1) Chapter Thaha 130:

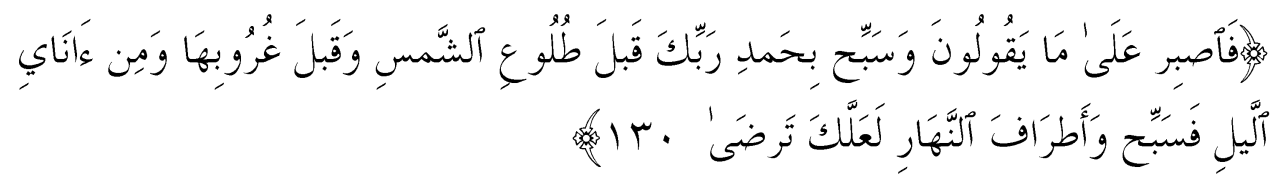

"And praise your Lord, before the sun rises and before it sets, and praise also at the times of the night and during the day, so that you may feel good",

2) Chapter Hud 114:

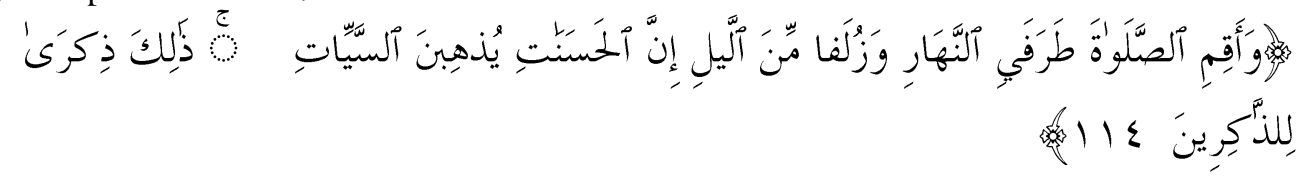

"And do the prayer on both sides of the day (morning and evening) and at the beginning of the night".

c. Shalat Schedules 
In Al-Quran, Allah said that shalat has specific time which has been determined. It has been mentioned on his commandment:

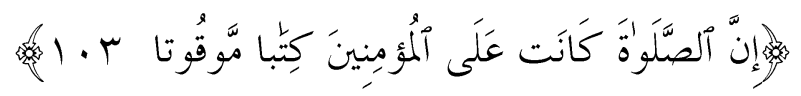

In fact, praying is an obligation which is determined by the time for those who have faith.

Then Prophet Muhammad determined the praying time on his hadith:

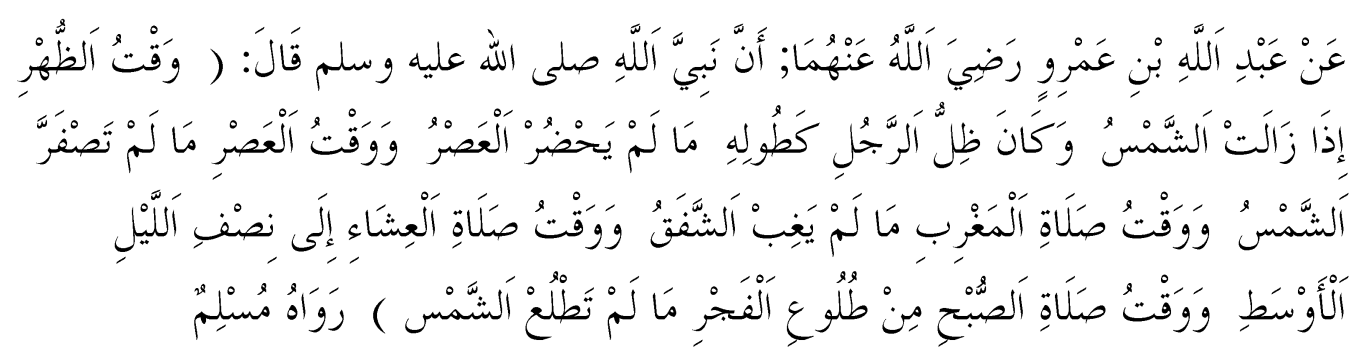

From Abdullah Ibn Amr Radliyallaahu 'anhu that Rasulullah Sallallaahu' alaihi wa Sallam said: "Dhuhr time is if the sun has tilted (to the west) and a person's shadow is the same as the height during Asr time has not arrived Asr time enters as long as the sun has not turned yellow during Maghrib prayer time. The red cloud has not disappeared from the time of Isha prayer until midnight and the time of Fajr prayer since dawn until the sun has not risen. " (Riwayat Muslim) (al Asqalany, no hadis 163)

According to above mentioned hadith and some researchs reveals about some praying schedule as follow:

1) Zuhur time

It started by the culmination of the sun (zawal) until the shadow of an object as long as the object. (Rahman Ritonga dan Zainuddin, 2002: 93). It according to Allah's commandment in chapter al-Isra' al-Isra'(17) 7:

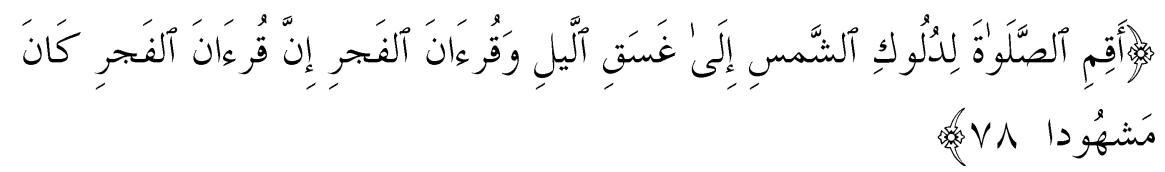

Do praying from after the sun slips until dark at night and (do praying) at dawn. Actually, the dawn prayer was witnessed (by angels).

The condition of Zuhur time in a certain place is the sun has been reached the top culmination on that place. The pattern show how to calculate the begining of zuhur time. $\mathrm{Zh}=\mathrm{KA}+\mathrm{i}$. $\mathrm{Zh}$ is zuhur time, $\mathrm{KA}$ means the top culmination. 
Then i stands for ikhtiyat, which counted according to determined place, the formula is $I=4 \mathrm{~L} .111 \cos Q$ unit $I$ is minutes. $\mathrm{L}$ is range from the center of a country or a city until to the western border area of the country or city with its unit is KM. Then Q stands for the latitude of the country or city. If we use the data from Ephimeris Hisab Rukyah book: the time of KA counted by the formula: $K A=(\lambda s-\lambda n) / 15+12-e n+i$

There are three time zones in Indonesia, so that the duhur time counted as follow:

Indonesian western time zone (WIB) $: \mathrm{Zh}=\left(105^{\circ}-\lambda \mathrm{n}\right) / 15+12-\mathrm{e} 5+$ i

Indonesian middle time zone (WITA): $\mathrm{Zh}=\left(120^{\circ}-\lambda \mathrm{n}\right) / 15+12-\mathrm{e} 4+\mathrm{i}$

Indonesian eastern time zone (WIT): $\mathrm{Zh}=\left(135^{\circ}-\lambda \mathrm{n}\right) / 15+12-\mathrm{e} 3+$ i

The correction of longitude time (Koreksi waktu bujur /KWB) is (standard longitude - zone longitude) : 15 so;

KWB1 is $\left(105^{\circ}-\lambda \mathrm{n}\right) / 15$

$\mathrm{KWB} 2$ is $\left(120^{\circ}-\lambda \mathrm{n}\right) / 15$

KWB 3 is $\left(135^{\circ}-\lambda \mathrm{n}\right) / 15$

For WIB, Zh = KWB $1+12-\mathrm{e} 5+\mathrm{i}$

For WITA, $\mathrm{Zh}=\mathrm{KWB} 2+12-\mathrm{e} 5+\mathrm{i}$

For WIT, Zh = KWB3 + 12 -e3 + i (Nailur Rahmi, 2008: 64)

2) Ashar Time

It begins with the end of Zuhur time when the shadow of an object is higher than the object untill the sunset (Nailur Rahmi, 2008)

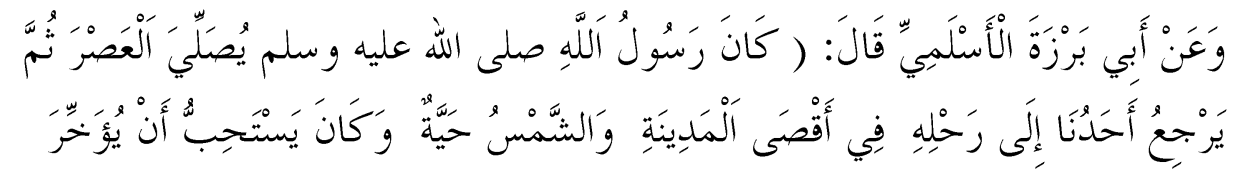

Abu Barzah al-Aslamy Radliyallaahu 'anhu said: Rasulullah Sallallaahu' alaihi wa Sallam once finished the Asr prayer and then one of us went back to his house at the end of the city of Medina while the sun was still hot. Muttafaq Alaihi. 
Another argument said that the beginning of Ashar time is when the shadow of an object as high as the object itself. (Dimsiki Hadi, 2009: 109). So, the requirement of the beginning of ashar time is if the shadow of istiwa' stick is added by the length of its shadow when the stick sunlit by the Sun on KA spot. The formula of ashar time is :

Cos $\mathrm{a}=\sin \mathrm{ha}: \cos \varphi: \cos \mathrm{d} 8-\operatorname{tg} \varphi \cdot \operatorname{tg} \mathrm{d} 8$

Ashar $=$ ta: $15+12-\mathrm{e} 8+\mathrm{KWB} 1+\mathrm{i}$

3) Magrib Time

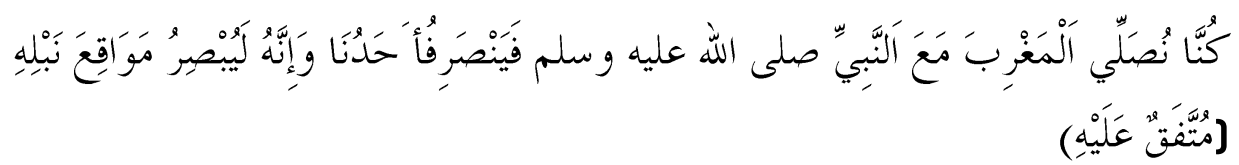

Rafi 'Ibn Kharij Radliyallaahu' anhu said: We once prayed Maghrib with Rasulullah Sallallaahu 'alaihi wa Sallam then one of us went home and he could still see the place where his arrow had fallen. Muttafaq Alaihi.

Magrib time begins since the sunset until the red cloud disappeared (Slamet Hambali, 2011: 129). The beginning of magrib time influenced three factors, that is:

a) The distant of the center of the sun to the real of horizon (hm),

b) The national latitude (Q),

c) The sun declination in the begining of magrib $(\mathrm{dm})$.

Generally $\mathrm{hm}$ is $-1^{\circ}$ and used as calculation of the beginning of magrib to the country which located on large-highland, so the factor of low horizon counted with the formula: $\mathrm{D}^{\prime}=1,76 \mathrm{~m} . \mathrm{M}=$ the place highness with metre unit from a large land. Therefore, the range of the spot center of the Sun since it culminated until sunset, counted with the formula: $\mathrm{hm}=$ $(\mathrm{D}+$ Refraksi $+\mathrm{SD})$ all in a minute bow. If the value of $\mathrm{hm}$ is known, we can find the angle of magrib time TM by the pattern as follow: Cos tm $=\sin \mathrm{hm}$ $: \cos \varphi: \cos \mathrm{d} 11-\operatorname{tg} \varphi \cdot \operatorname{tg} 11$. Then calculating magrib time with formula: $\mathrm{Mg}$ = tm: 15+12-e11+KWB1+i. (Nailur Rahmi, 2008: 65-66)

4) Isya Time 
The Isya time is determined according to Prophet Muhammad's utterance, which said:

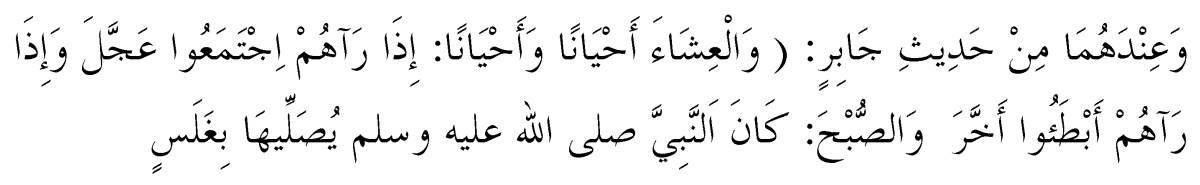

According to the hadith Bukhari-Muslim from Jabir: Sometimes he performed the Isha prayer 'at the beginning of his time and sometimes he did it at the end of his time. If he saw that they had gathered he immediately did it and if he saw them too late he ended it when he was about the Fajr prayer, usually the Prophet sallallaahu 'alaihi wa Sallam did it when it was still dark.

The Isya time is started by the sign of fading the red light or Asy syafar al-Ahmar in the western sky, which is a sign of the dark night. The phenomenon is known in Falak science as the end of astoronomical twillight (Nailur Rahmi, 2008: 132). At the moment the position of the Sun is 18 degree under the west horizon or the range of zenithal sun is 180 degree. Another argument said that Isya' time is started a moment after we finished magrib prayer. The sun declination in the begining of isya referred from Ephimeris HR book: in the west Indonesian time zone is d12. With the pattern:

Cos ti = sin hi, $\cos \varphi: \operatorname{Cos} \mathrm{d} 12-\mathrm{d} 12 \operatorname{tg} \varphi \cdot \operatorname{tg} \mathrm{d} 12$

Isya $\quad=\mathrm{ti}: 15+12-\mathrm{e} 12+\mathrm{KWB} 1+\mathrm{i}$

5) Shubuh Time

The divine word of Allah stated that shubuh time is explained in the chapter of al-Isra, 78:

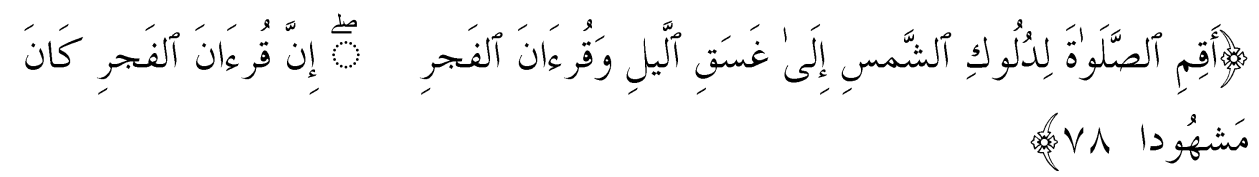

Do praying from after the sun slips until dark at night and (do praying) at dawn. In fact, the dawn prayer was witnessed (by angels) 


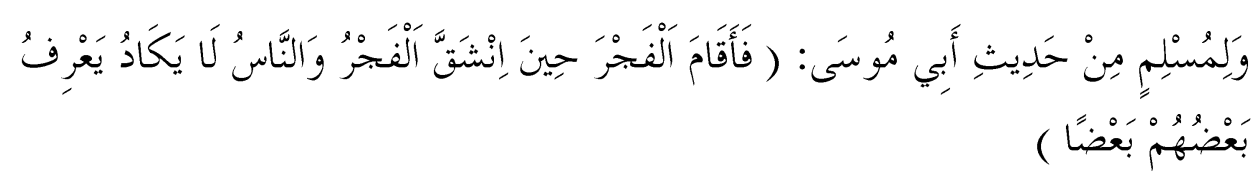

According to Muslim from the hadith of Abu Musa: He performed the Fajr prayer at dawn when the people barely knew each other.

The shubuh time is applied since dawn (fajar shadik) emmerged until the sun rises (Sayyid Sabiq, tt: 182). The requirement of the begining of shubuh time is when the distant of the spot centre of the sun to the real horizon is $-20^{\circ}$, we can find the number from the following data:

a) The low of ufuk mar'i $=-10^{\prime}$

b) Refraction = $=-34$ '

c) The red Syafar $\quad=-17$ '

d) The dawn (Fajar sidik) = 2'

e) $\mathrm{SD}$ of the sun $=-16^{\prime}$

The HS is accumulated so overall it will be $-20^{\circ}$

The angle time is counted with pattern as follow:

Cos ts $=\sin$ hs $:$ hs $\operatorname{Cos} \varphi: \cos d-2-\operatorname{tg} \varphi \cdot \operatorname{tgd}-2$

Subuh $=-$ ts: $15=12-\mathrm{e}-2+\mathrm{KWB}+\mathrm{i}$

\section{Hisab of All the Time Praying Schedule}

Several sections are used to determine the begining of praying schedule, as follow:

1. The First Section

The first section is arranging the schedules. On the left side, there are some number which show latitudes; letter $\mathrm{U}$ stands for north latitude and letter $\mathrm{S}$ stands for south latitude. These number started with $7^{\circ}$ north latitude on the top, then followed by $6^{\circ}, 5^{\circ}, 4^{\circ}$, consecutively until $0^{\circ}$ north latitude. Then it continued to $1^{\circ}$ south latitude downward until reached to $10^{\circ}$ south latitude. On the right side of each number is stated praying schedules; Subuh, Syuruk, Zuhur, Ashar, Magrib and Isya for each related latitudes. The number of hours and minutes are completed. 
These schedule are noted according to local mean time (washati). (Sa'aduddin Djambek, 1974: 12)

Every schedule of Sa'aduddin Djambek's method is made for Gregorian calendar which is written on the top of schedule. The included date is $1,4,7,10$, $13,16,19,22,25,28$, as well as 31 for the month which has $31^{\text {st }}$ days. We can also use the date which close to those date, for example we can use the schedule of $1^{\text {st }}$ date for the $2^{\text {nd }}$ date, or we can use the schedule of the $4^{\text {th }}$ date for the $3^{\text {rd }}$ date, and so on. (Sa'aduddin Djambek, 1974: 48) For the $30^{\text {th }}$ date, we can use the schedule of the $31^{\text {st }}$ date. If the month is only 30 days, so the schedule is referred to the $1^{\text {st }}$ date of the following month, for example the schedule of $30^{\text {th }}$ April is referred from $1^{\text {st }}$ May. Therefore, every date on the schedule mostly used for three consecutive days, such as the $22^{\text {nd }}$ date is used for the date 21,22 , and 23 .

To illustrate, author provides an example of praying schedule using Sa'aduddin Djambek's method. The schedule is for 22 February which is also valid for 21, 22, and 23 of February, as follow:

\begin{tabular}{|c|c|c|c|c|c|c|}
\hline Latitude & Subuh & Syuruq & Zuhur & Ashar & Magrib & Isya \\
\hline $\mathrm{U} 7^{\circ}$ & 04.57 & 06.15 & 12.14 & 15.34 & 18.13 & 19.22 \\
\hline 6 & 04.57 & 06.14 & 12.14 & 15.33 & 18.13 & 19.23 \\
\hline 5 & 04.56 & 06.13 & 12.14 & 15.33 & 18.14 & 19.23 \\
\hline U 4 & 04.55 & 06.13 & 12.14 & 15.32 & 18.15 & 19.24 \\
\hline 3 & 04.54 & 06.12 & 12.14 & 15.32 & 18.16 & 19.25 \\
\hline 2 & 04.54 & 06.11 & 12.14 & 15.31 & 18.16 & 19.25 \\
\hline U 1 & 04.53 & 06.10 & 12.14 & 15.30 & 18.17 & 19.26 \\
\hline 0 & 04.52 & 06.10 & 12.14 & 15.30 & 18.18 & 19.27 \\
\hline S 1 & 04.51 & 06.09 & 12.14 & 15.29 & 18.18 & 19.28 \\
\hline 2 & 04.51 & 06.08 & 12.14 & 15.28 & 17.19 & 19.28 \\
\hline 3 & 04.50 & 06.07 & 12.14 & 15.27 & 17.20 & 19.29 \\
\hline 4 & 04.49 & 06.07 & 12.14 & 15.26 & 17.21 & 19.30 \\
\hline 5 & 04.48 & 06.06 & 12.14 & 15.25 & 17.21 & 19.31 \\
\hline 6 & 04.47 & 06.05 & 12.14 & 15.23 & 17.22 & 19.32 \\
\hline 7 & 04.46 & 06.04 & 12.14 & 15.22 & 17.23 & 19.33 \\
\hline
\end{tabular}




\begin{tabular}{|cc|c|c|c|c|c|c|}
\hline & & & & & & & \\
$\mathrm{S}$ & 8 & 04.45 & 06.04 & 12.14 & 15.21 & 17.24 & 19.34 \\
& 9 & 04.44 & 06.03 & 12.14 & 15.19 & 17.24 & 19.35 \\
& 10 & 04.43 & 06.02 & 12.14 & 15.17 & 17.25 & 19.36 \\
\hline
\end{tabular}

2. The Second Section

In the second section, there is a list of some cities from large islands or islands whose the time zones are same.

a. Cities in Sumatra island in Western Indonesian time zone.

b. Cities in Java and Bali in Western Indonesian time zone.

c. Cities in Kalimantan (Borneo) island in Middle Indonesian time zone, and some cities in Northern Kalimantan are included.

d. Cities in Sulawesi in Middle Indonesian time zone.

e. Cities in Nusatenggara in Middle Indonesian time zone.

f. Cities in Moluccas Island and West Papua in Eastern Indonesian time zone.

Moreover, some cities in Malayan Peninsula also included with Western Malaysian time zone. The cities name are listed on it alphabetically. (Sa'aduddin Djambek, 1974: 10-11)

There are three columns on the right side of the list cities. The first column contains latitude of the related city until one tenth degree. The second column contains longitude of related city until one tenth degree. The third column contains the number of minutes to adjust and correct the time from the first section in order to suit with the local time. The sign $(+)$ means that we have to add the minutes of time obtained from first section. The sign $(-)$ means that the correction time have to be reduced. Then, if there is a 0 number, so the time from first section can be used without correction.

The correction on the third column have to be implemented to all praying times (Subuh, Syuruq, Zuhur, Ashar, Magrib, Isya) which obtained from the first section schedule. (Sa'aduddin Djambek, 1974: 11) 
To illustrate, author describe a table and data particuliarly from Sumatra island as follow:

The Western Indonesian time zone (Bujur 105) (Sa'aduddin Djambek, 1974: 93 96)

\begin{tabular}{|l|l|l|l|}
\hline $\begin{array}{l}\text { Countries or Cities } \\
\text { Name }\end{array}$ & Latitude & Longitude & Correction \\
\hline Airbangis & U 0.2 & 99.4 & $+22 \mathrm{~m}$ \\
Alahan Pajang & S 1.1 & 100.8 & $+17 \mathrm{~m}$ \\
Banda Aceh & U 2.4 & 99.0 & $+39 \mathrm{~m}$ \\
Bangkinang & U 0.4 & 101.0 & $+16 \mathrm{~m}$ \\
Batusangkar & S 0.5 & 100.6 & $+18 \mathrm{~m}$ \\
Buo & S 0.5 & 100.8 & $+17 \mathrm{~m}$ \\
Bukittinggi & S 0.3 & 100.4 & $+19 \mathrm{~m}$ \\
Bonjol & 00 & 100.2 & $+19 \mathrm{~m}$ \\
Jambi & S 1.6 & 103.6 & $+6 \mathrm{~m}$ \\
Medan & U 3.6 & 98.6 & $+25 \mathrm{~m}$ \\
Padang & S 1.0 & 100.4 & $+19 \mathrm{~m}$ \\
Padang Panjang & S 0.5 & 100.4 & $+18 \mathrm{~m}$ \\
Pekanbaru & U 0.5 & 101.5 & $+14 \mathrm{~m}$ \\
Palembang & S 0.5 & 10.4 & $+1 \mathrm{~m}$ \\
Payahkumbuh & S 0.2 & 100.6 & $+18 \mathrm{~m}$ \\
Sawahlunto & S 0.7 & 100.8 & $+17 \mathrm{~m}$ \\
Sijunjung & S 0.7 & 101.0 & $+16 \mathrm{~m}$ \\
Singkarak & S 0.7 & 100.6 & $+18 \mathrm{~m}$ \\
Solok & S 0.8 & 100.6 & $+18 \mathrm{~m}$ \\
Talu & U 0.2 & 100.0 & $+20 \mathrm{~m}$ \\
& & & \\
\hline
\end{tabular}

3. Analysist of Hisab Method for the Beginning of Praying Schedule. Hisab for Praying Schedule in Banda Aceh, 21 February 2020

a) The begining of Subuh time

Cos ts $=\operatorname{Sin}$ hs $: \operatorname{Cos} \varphi: \operatorname{Cos} \mathrm{d}-2-\operatorname{Tg} \varphi \times \operatorname{Tg} \mathrm{d}-2$

$\operatorname{Cos} t \mathrm{~s}=\operatorname{Sin}\left(-20^{\circ}\right): \operatorname{Cos}\left(05^{\circ} 34^{\prime}\right): \operatorname{Cos}\left(-10^{\circ} 29^{\prime} 46.5^{\prime \prime}\right)-\operatorname{Tg}\left(05^{\circ} 34^{\prime}\right) \times \operatorname{Tg}((-$ $\left.10^{\circ} 29^{\prime} 46.5^{\prime \prime}\right)$

Cos ts $=(-0.34202):(0.99528):(0.98327)-(0.09746) \times(-0.18527)$

Cos ts $=(-0.34949)-(-0.01806)$

$=-0.33143=109.35559$ 


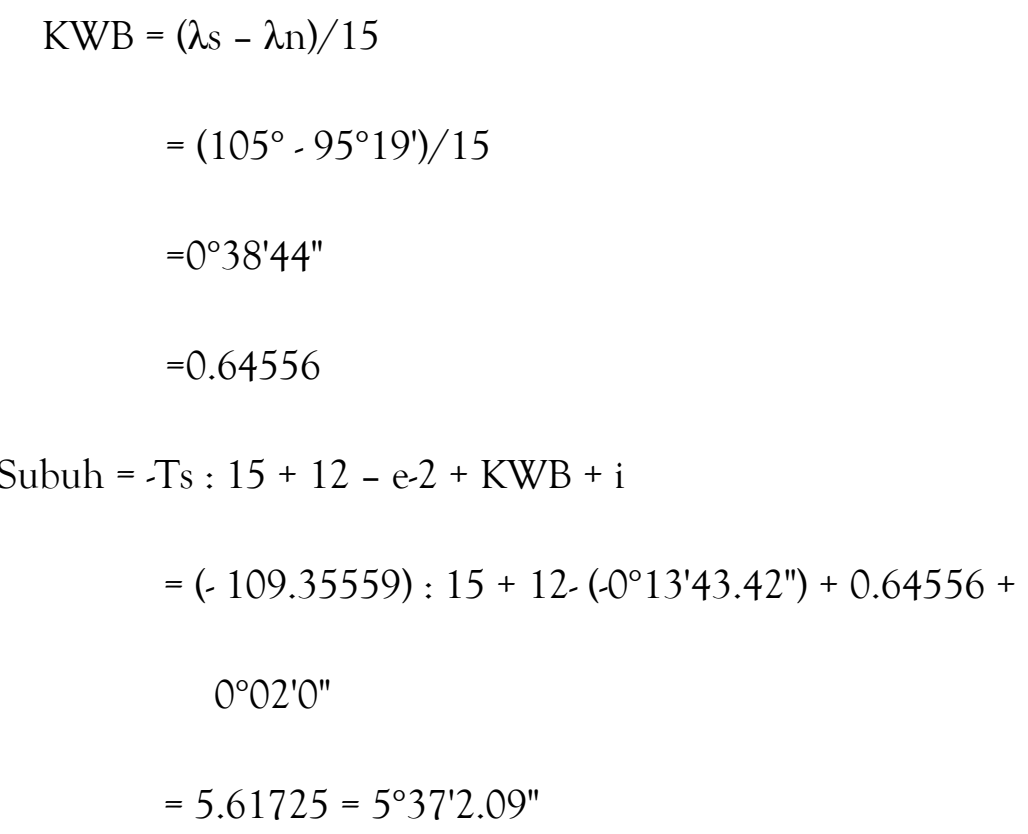

Subuh= 05.37 WIB

b) The Begining of Zuhur

$$
\begin{aligned}
\mathrm{Zh}=\mathrm{KA}+\mathrm{i} & \\
\mathrm{KA} & =(\lambda s-\lambda \mathrm{n}) / 15+12-\mathrm{e} 5 \\
& =\left(105^{\circ}-95^{\circ} 19^{\prime}\right) / 15+12-\left(-0^{\circ} 13^{\prime} 42^{\prime \prime}\right) \\
& =9^{\circ} 40^{\prime} 0^{\prime \prime} / 15+12-0^{\circ} 2^{\prime} 52^{\prime \prime} \\
& =12.87389 \\
& =12^{\circ} 52^{\prime} 26^{\prime \prime}+0^{\circ} 2^{\prime} 0^{\prime \prime} \\
& =12.90722=12^{\circ} 54^{\prime} 26^{\prime \prime} \\
& =12.54 \mathrm{WIB}
\end{aligned}
$$

c) The Begining Ashar

$$
\begin{aligned}
Z \mathrm{~m}=(\mathrm{Q}-\mathrm{d} 5) & \\
= & \left(05^{\circ} 34^{\prime}--10^{\circ} 45^{\prime} 05^{\prime \prime}\right) \\
& =16^{\circ} 19^{\prime} 05^{\prime \prime} \\
\mathrm{Tg} \mathrm{h} & =\frac{1}{} \\
& 1+\operatorname{tg} \mathrm{zm} \\
= & \frac{1}{1+\operatorname{tg}\left(16^{\circ} 19^{\prime} 05^{\prime \prime}\right)}
\end{aligned}
$$




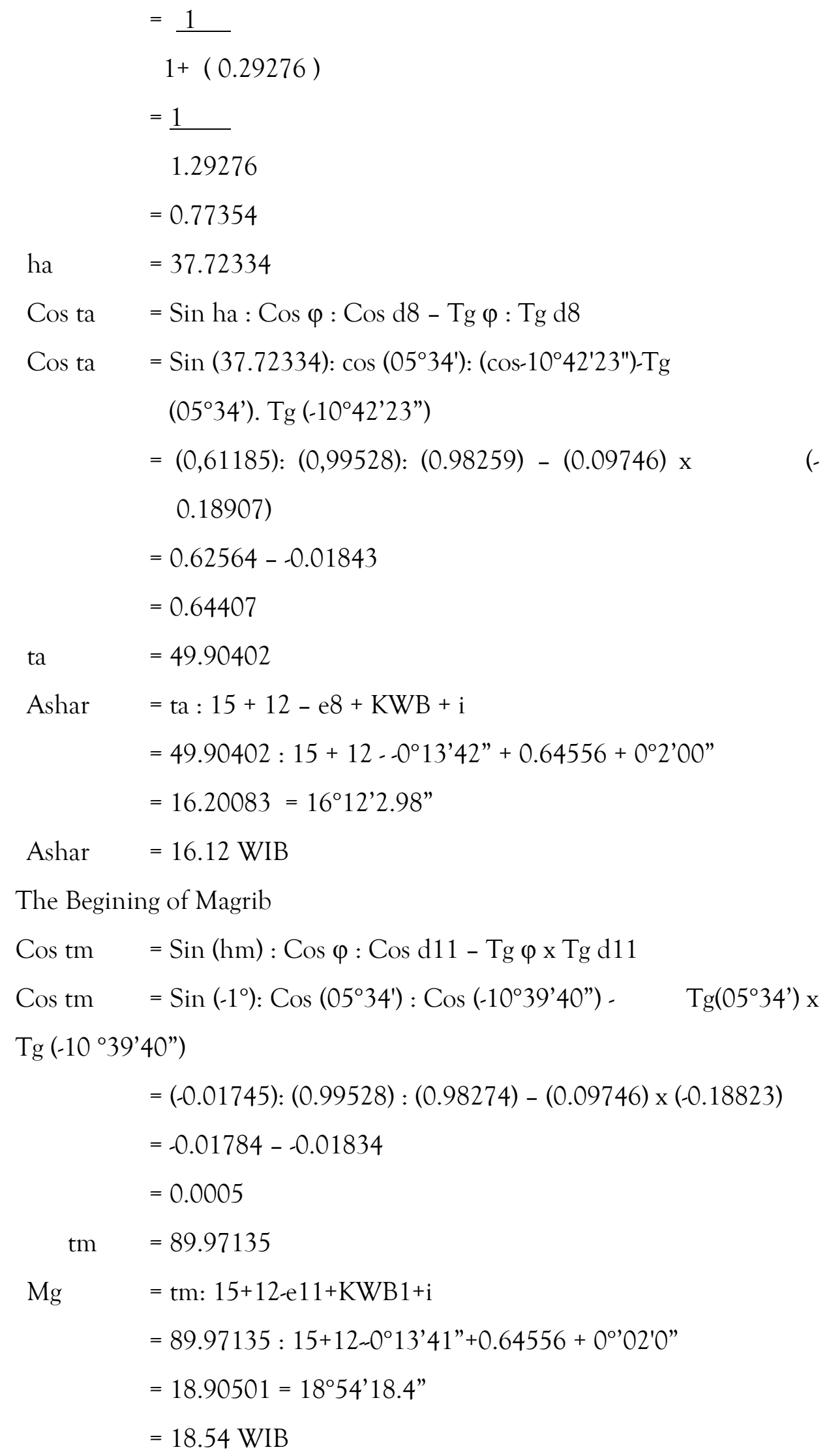


e) The Begining of Isya

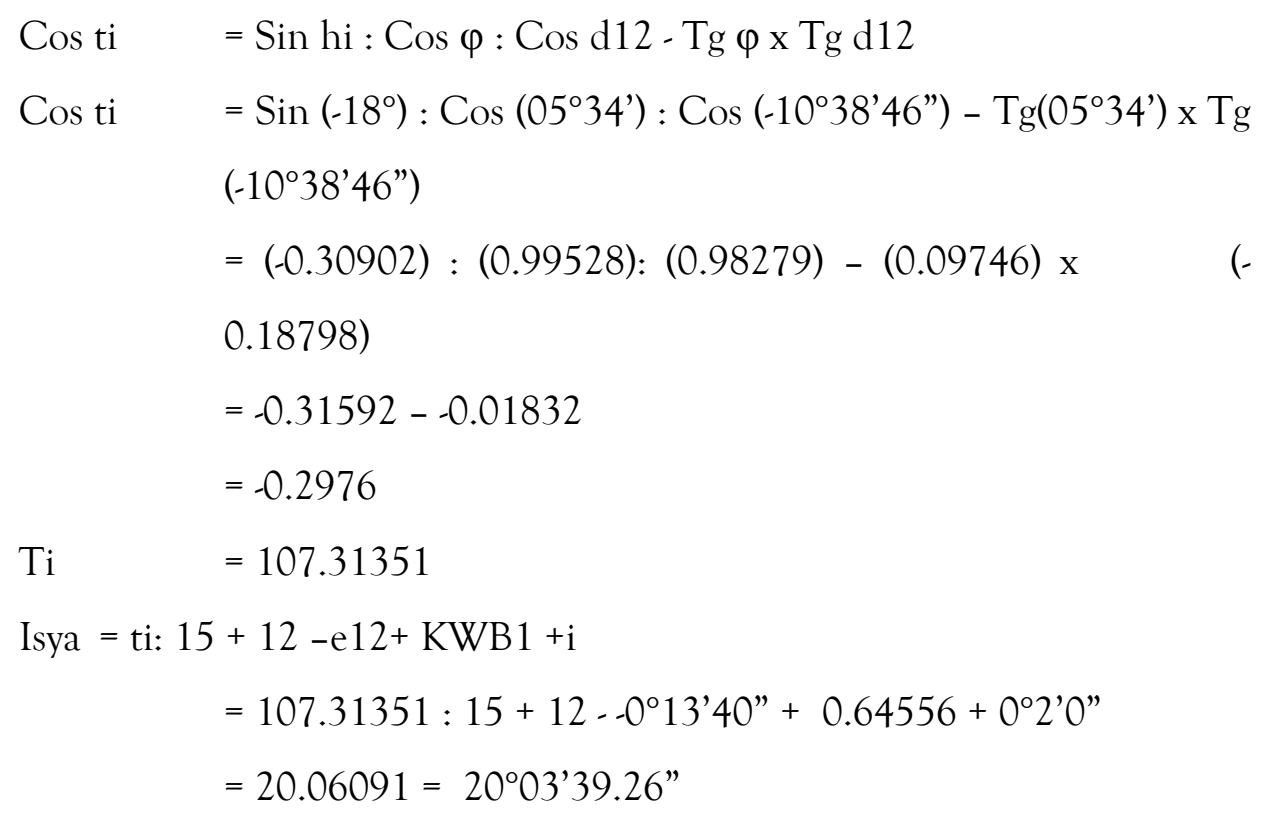

Isya $=20.04 \mathrm{WIB}$

1. Hisab of praying schedule for Batusangkar, 21 February 2020

a) The Begining of Subuh

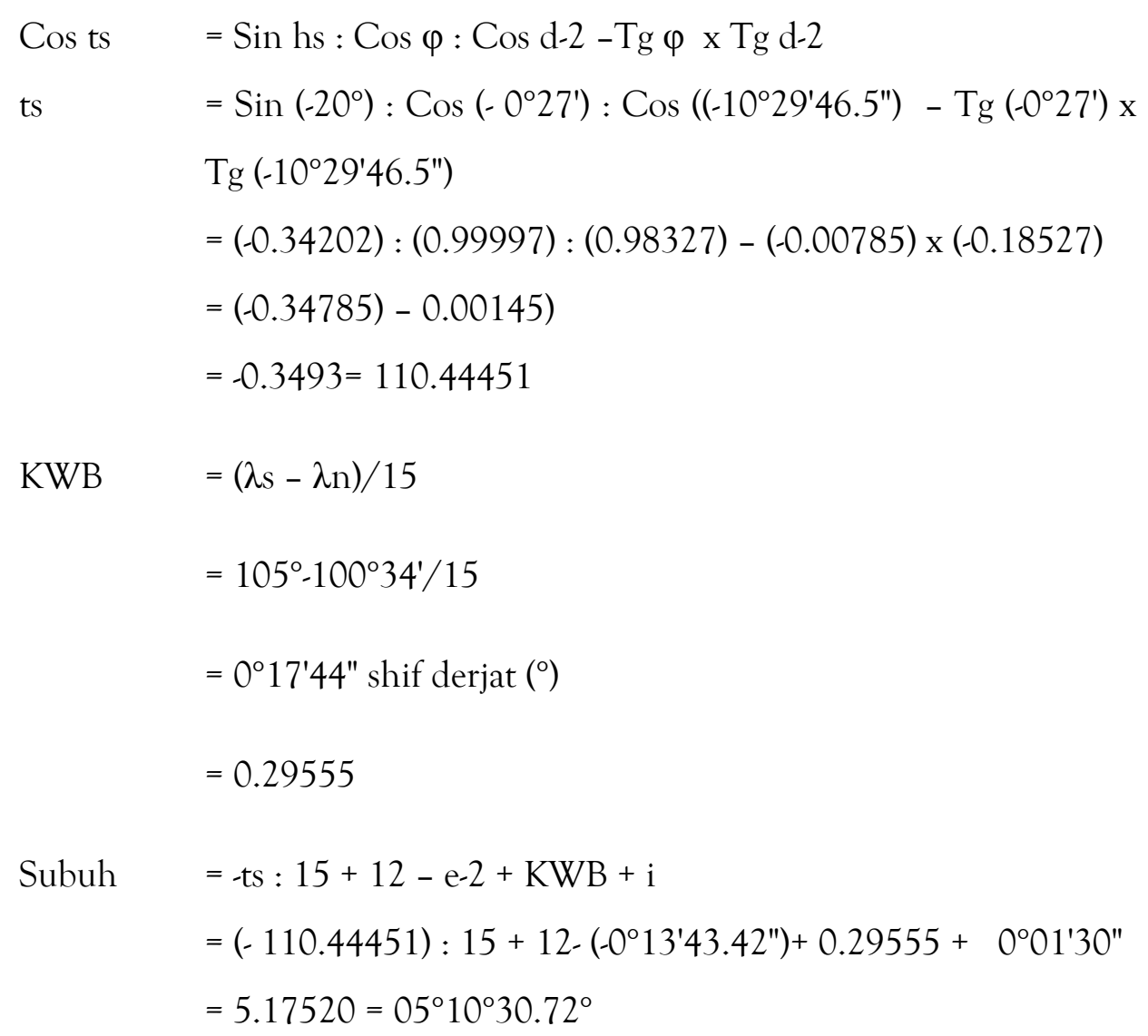


Subuh $\quad=05.11 \mathrm{WIB}$

b) The Begining of Zuhur

$\mathrm{Zh}=\mathrm{KA}+\mathrm{i}$

$$
\begin{aligned}
\mathrm{KA} & =(\lambda \mathrm{s}-\lambda \mathrm{n}) / 15+12-\mathrm{e} 5 \\
& =\left(105^{\circ}-100^{\circ} 34^{\prime}\right) / 15+12-0^{\circ} 13^{\prime} 42^{\prime \prime} \\
& =4^{\circ} 26^{\prime} 0^{\prime \prime} / 15+12-0^{\circ} 2^{\prime} 52^{\prime \prime} \\
& =12.52389=12^{\circ} 31^{\prime} 26^{\prime \prime} \\
\text { Zuhur } \quad & =12^{\circ} 31^{\prime} 26^{\prime \prime}+0^{\circ} 01^{\prime} 30^{\prime \prime} \\
& =12.54889=12^{\circ} 32^{\prime} 56^{\prime \prime} \\
& =12.33 \mathrm{WIB}
\end{aligned}
$$

c) The Begining of Ashar

$$
\begin{aligned}
& \mathrm{Zm}=(\mathrm{Q}-\mathrm{d} 5) \\
& =\left(-0^{\circ} 27^{\prime}-10^{\circ} 45^{\prime} 05^{\prime \prime}\right) \\
& =10^{\circ} 18^{\prime} 05^{\prime \prime} \\
& =\underline{1} \\
& 1+\operatorname{tg} z \mathrm{~m} \\
& =1 \\
& 1+\operatorname{tg}\left(10^{\circ} 18^{\prime} 05^{\prime \prime}\right) \\
& =\underline{1} \\
& 1+(0.18176) \\
& =\underline{1} \\
& 1.18176 \\
& =0.84620 \\
& \text { ha } \quad=40.23774 \\
& \text { Cos ta = Sin ha }: \operatorname{Cos} \varphi: \operatorname{Cos} d 8-\operatorname{Tg} \varphi: \operatorname{Tg} d 8 \\
& \text { Cos ta } \quad=\sin (40.23774): \cos \left(-0^{\circ} 27^{\prime}\right): \operatorname{Cos}\left(-10^{\circ} 42^{\prime} 23^{\prime \prime}\right)-\operatorname{Tg} \\
& \left(-0^{\circ} 27^{\prime}\right) \times \operatorname{Tg}\left(-10^{\circ} 42^{\prime} 23^{\prime \prime}\right) \\
& =(0.64596):(0.99997):(0.98259)-(-0.00785) \mathrm{x} \\
& (-0.18907) \\
& =0.65743-(0.00148)
\end{aligned}
$$


$=0.65595$

ta $\quad=49.00828$

Ashar $=$ ta $: 15+12-\mathrm{e} 8+\mathrm{KWB}+\mathrm{i}$

$=49.00828: 15+12-0^{\circ} 13^{\prime} 42^{\prime \prime}+0.29555+\quad 0^{\circ} 01^{\prime} 30^{\prime \prime}$

$=15.81610=15^{\circ} 48^{\prime} 57.97^{\prime \prime}$

Ashar $\quad=15.49 \mathrm{WIB}$

d) The Begining of Magrib

$\operatorname{Cos} \mathrm{tm} \quad=\operatorname{Sin}(\mathrm{hm}): \operatorname{Cos} \varphi: \operatorname{Cos} \mathrm{d} 11-\operatorname{Tg} \varphi \times \operatorname{Tg} \mathrm{d} 11$

$\operatorname{Cos} \mathrm{tm} \quad=\operatorname{Sin}\left(-1^{\circ}\right): \operatorname{Cos}\left(-0^{\circ} 27^{\prime}\right): \operatorname{Cos}\left(-10^{\circ} 39^{\prime} 40^{\prime \prime}\right)-$ $\operatorname{Tg}\left(-0^{\circ} 27^{\prime}\right) \times \operatorname{Tg}\left(-10^{\circ} 39^{\prime} 40^{\prime \prime}\right)$

$=(-0.01745):(0.99997):(0.98274)-(-0.00785) \times(-0.18825)$

$=-0.01776-0.00148$

$=-0.01924$

$\mathrm{tm} \quad=91.10244$

$\mathrm{Mg}=\mathrm{tm}: 15+12-\mathrm{e} 11+\mathrm{KWB} 1+\mathrm{i}$

$=91.10244: 15+12-0^{\circ} 2^{\prime} 54 "+0.29556+0^{\circ} 1^{\prime} 30^{\prime \prime}$

$=18.62210=18^{\circ} 37^{\prime} 19.57 . "$

$=18.37 \mathrm{WIB}$

e) The Begining of Isya

Cos ti $\quad=$ Sin hi $: \operatorname{Cos} \varphi: \operatorname{Cos} d 12-\operatorname{Tg} \varphi \times \operatorname{Tg} d 12$

$\operatorname{Cos}$ ti $\quad=\operatorname{Sin}\left(-18^{\circ}\right): \operatorname{Cos}\left(-0^{\circ} 27^{\prime}\right): \operatorname{Cos}\left(-10^{\circ} 38^{\prime} 46^{\prime \prime}\right)-\operatorname{tg}\left(-0^{\circ} 27^{\prime}\right) \times \operatorname{Tg}(-$ $\left.10^{\circ} 38^{\prime} 46^{\prime \prime}\right)$

$=(-0.30902):(0.99997):(0.98279)--(0.00785) \mathrm{x}$

$0.18798)$

$=-0.31444-0.00148$

$=-0.31592$

ti $\quad=108.41636$

Isya $=\mathrm{ti}: 15+12-\mathrm{e} 12+\mathrm{KWB} 1+\mathrm{i}$

$=108.41636: 15+12-0^{\circ} 13^{\prime} 40^{\prime \prime}+0.29555+0^{\circ} 1^{\prime} 30^{\prime \prime}$

$=19.77609=19^{\circ} 46^{\prime} 33,91^{\prime \prime}$

Isya $=19.47 \mathrm{WIB}$ 
2. Hisab of praying schedule for Jambi, 21 February 2020

a) The Begining of Subuh

Cos ts $\quad=$ Sin hs $: \operatorname{Cos} \varphi: \operatorname{Cos} d-2-\operatorname{Tg} \varphi \times \operatorname{Tg} d-2$

ts $\quad=\operatorname{Sin}\left(-20^{\circ}\right): \operatorname{Cos}\left(-1^{\circ} 36^{\prime \prime}\right): \operatorname{Cos}\left(\left(-10^{\circ} 29^{\prime} 46.5^{\prime \prime}\right)-\operatorname{Tg}\left(-1^{\circ} 36^{\prime}\right) \mathrm{x}\right.$

$\operatorname{Tg}\left(-10^{\circ} 29^{\prime} 46.5^{\prime \prime}\right)$

$=(-0.34202):(0.99961):(0.98327)-(-0.02793) \times(-0.18527)$

$=(-0.34798)-0.00517)$

$=-0.35315=110.68010$

KWB $\quad=(\lambda s-\lambda \mathrm{n}) / 15$

$=105^{\circ}-103^{\circ} 38^{\circ} / 15$

$=0^{\circ} 5^{\prime} 28^{\prime \prime}$

$=0.09111$

Subuh = -ts $: 15+12-\mathrm{e}-2+\mathrm{KWB}+\mathrm{i}$

$=(-110.68010): 15+12-\left(-0^{\circ} 13^{\prime} 43.42^{\prime \prime}\right)+0.09111+0^{\circ} 01^{\circ} 30^{\circ}$

$=4.96616=04^{\circ} 57^{\prime} 58.19^{\prime \prime}$

Subuh $\quad=04.58 \mathrm{WIB}$

b) The Begining of Zuhur

$$
\mathrm{Zh}=\mathrm{KA}+\mathrm{i}
$$

$\mathrm{KA}=(\lambda \mathrm{s}-\lambda \mathrm{n}) / 15+12-\mathrm{e} 5$

$=\left(105^{\circ}-103^{\circ} 36^{\prime}\right) / 15+12--^{\circ} 13^{\prime} 42^{\prime \prime}$

$=4^{\circ} 26^{\prime} 0^{\prime \prime} / 15+12-0^{\circ} 2^{\prime} 52^{\prime \prime}$

$=12.32167=12^{\circ} 19^{\prime} 18^{\prime \prime}$

Zuhur $\quad=12^{\circ} 19^{\prime} 18^{\prime \prime}+0^{\circ} 01^{\prime} 30^{\prime \prime}$

$=12.34666=12^{\circ} 20^{\prime} 48^{\prime \prime}$

$=12.21 \mathrm{WIB}$

c) The Begining of Ashar

$$
\begin{aligned}
\mathrm{Zm}=(\mathrm{Q}-\mathrm{d} 5) & \\
= & \left(-1^{\circ} 36^{\prime}--10^{\circ} 45^{\prime} 05^{\prime \prime}\right) \\
= & 9^{\circ} 9^{\prime} 5^{\prime \prime} \\
\text { Tg ha } \quad & \frac{1}{1+\operatorname{tg} \mathrm{zm}}
\end{aligned}
$$

Al-Hilal: Journal of Islamic Astronomy, Vol. 2, No. 1, Tahun 2020 


$$
\begin{aligned}
& =\frac{1}{1+\operatorname{tg}\left(9^{\circ} 9^{\prime} 5^{\prime \prime}\right)} \\
& =\frac{1}{1+(0.16109)} \\
& =\underline{1} \\
& =0.86126
\end{aligned}
$$

ha $\quad=40.73699$

Cos ta $=$ Sin ha: $\operatorname{Cos} \varphi: \operatorname{Cos} d 8-\operatorname{Tg} \varphi: \operatorname{Tg} d 8$

Cos ta $\quad=\sin (40.73699): \cos \left(-1^{\circ} 36^{\prime}\right): \operatorname{Cos}\left(-10^{\circ} 42^{\prime} 23^{\prime \prime}\right)-\operatorname{Tg}$

$\left(-1^{\circ} 36^{\prime}\right) \times \operatorname{Tg}\left(-10^{\circ} 42^{\prime} 23^{\prime \prime}\right)$

$=(0.65259):(0.99961):(0.98259)-(-0.02793) \mathrm{x}$

$(-0.18907)$

$=0.66441-(0.00528)$

$=0.65913$

ta $\quad=48.76644$

Ashar $\quad=$ ta $: 15+12-\mathrm{e} 8+\mathrm{KWB}+\mathrm{i}$

$=48.76644: 15+12-0^{\circ} 13^{\prime} 42^{\prime \prime}+0.09111+0^{\circ} 01^{\prime} 30^{\prime \prime}$

$=15.59554=15^{\circ} 35^{\prime} 43.94^{\prime \prime}$

Ashar $\quad=15.36 \mathrm{WIB}$

d) The Begining of Magrib

$$
\begin{aligned}
\operatorname{Cos} \mathrm{tm}= & \operatorname{Sin}(\mathrm{hm}): \operatorname{Cos} \varphi: \operatorname{Cos} \mathrm{d} 11-\operatorname{Tg} \varphi \times \operatorname{Tg} \mathrm{d} 11 \\
\operatorname{Cos} \mathrm{tm}= & \operatorname{Sin}\left(-1^{\circ}\right): \operatorname{Cos}\left(-1^{\circ} 36^{\prime}\right): \operatorname{Cos}\left(-10^{\circ} 39^{\prime} 40^{\prime \prime}\right)- \\
& \operatorname{Tg}\left(-1^{\circ} 36^{\prime}\right) \times \operatorname{Tg}\left(-10^{\circ} 39^{\prime} 40^{\prime \prime}\right) \\
= & (-0.01745):(0.99961):(0.98274)-(-0.02793) \times(-0.18825) \\
= & -0.01776-0.00526 \\
= & -0.02302 \\
= & 91.31906 \\
= & \operatorname{tm}: 15+12-\mathrm{e} 11+\mathrm{KWB} 1+\mathrm{i} \\
= & 91.31906: 15+12-0^{\circ} 13^{\prime} 41^{\prime \prime}+0.09111+0^{\circ} 1^{\prime} 30^{\prime \prime} \\
\mathrm{tm} \quad & 18.43210=18^{\circ} 25^{\prime} 55.57 . ”
\end{aligned}
$$


$=18.26 \mathrm{WIB}$

e) The begining of Isya

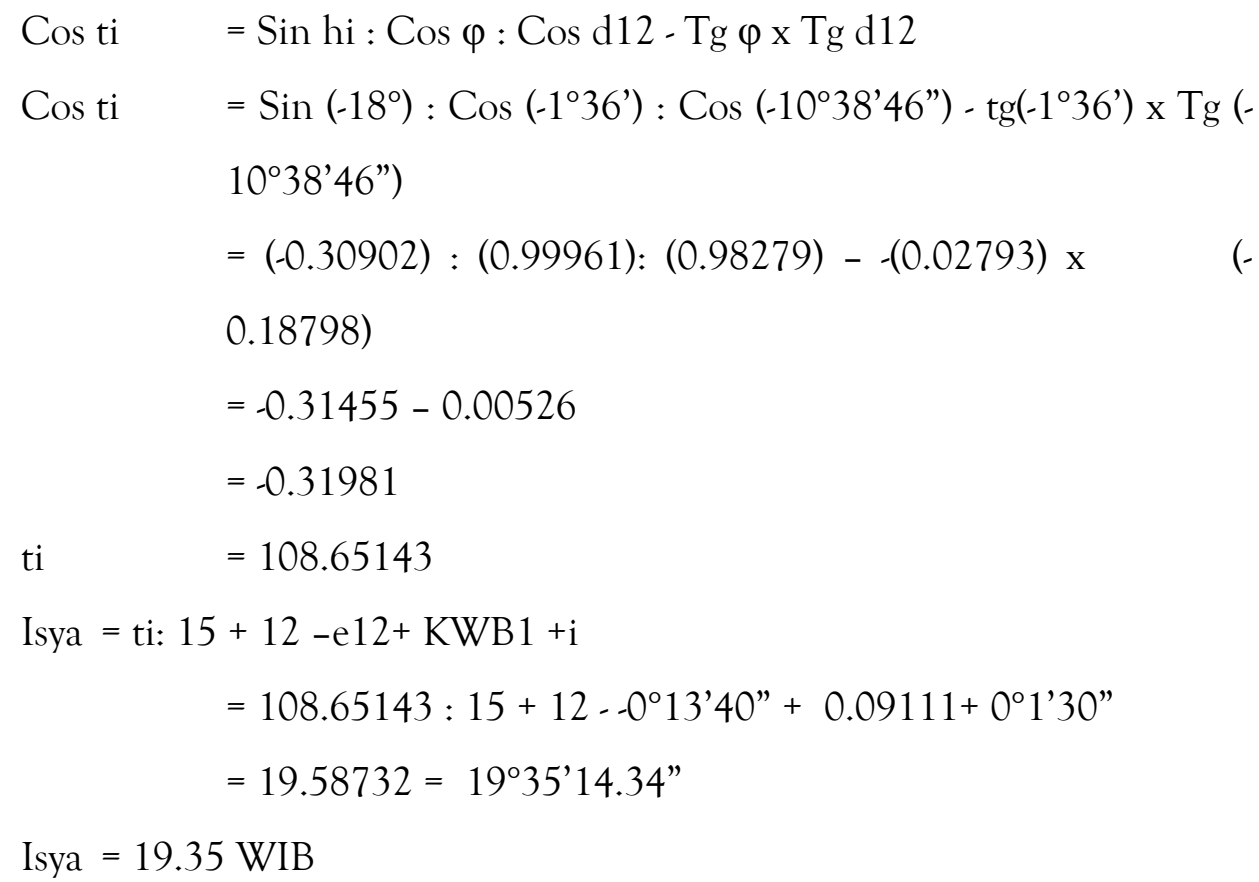

Hisab of all the time praying schedule.

1. The begining of praying schedule in Banda Aceh In the second section table, it is found the data latitude $U$ 5,6 North Latitude (LU), correction +39 m.5, 6 to be completed to 6

a) Subuh Time

In the first section table (table 22 February) is obtained that subuh time on latitude $U 6$ is at 04.57 a.m., then it is added with the correction 39, so the subuh time is; $04.57+00.39=05.36$. west Indonesian time zone (WIB).

b) Zuhur Time

In the first section table (table 22 February) is obtained that zuhur time on latitude $\mathrm{U} 6$ is 12.14 , then it added with the correction 39, so zuhur time is $; 12.43+00.39=12.53$ west Indonesian time zone (WIB).

c) Ashar Time 
In the first section table (table 22 February) is obtained that ashar time on latitude $\mathrm{U} 6$ is 15.33 , then it added with the correction 39, so ashar time is; $15.33+00.39=16.12$ west Indonesian time zone (WIB).

d) Magrib Time

In the first section table (table 22 February) is obtained that maghrib time on latitude $\mathrm{U} 6$ is 18.13, then it added with the correction 39, so maghrib time is; $18.13+00.39=18.52$ west Indonesian time zone (WIB).

e) Isya Time

In the first section table (table 22 February) is obtained that isya time on latitude $\mathrm{U} 6$ is 19.23 , then it added with the correction 39 , so isya time is; 19.23 $+00.39=20.02$ west Indonesian time zone (WIB).

In short, we can see the hisab result as the following table:

Table 1

The begining of praying schedule in Banda Aceh

\begin{tabular}{|l|l|l|l|}
\hline Shalat/Praying & All the time hisab & Contemporer hisab & Differences \\
\hline Subuh & $05.36 \mathrm{WIB}$ & $05.37 \mathrm{WIB}$ & 1 minute \\
\hline Zuhur & $12.53 \mathrm{WIB}$ & $12.54 \mathrm{WIB}$ & 1 minute \\
\hline Ashar & $16.12 \mathrm{WIB}$ & $16.12 \mathrm{WIB}$ & - \\
\hline Magrib & $18.52 \mathrm{WIB}$ & $18.54 \mathrm{WIB}$ & 2 minute \\
\hline Isya & $20.02 \mathrm{WIB}$ & $20.04 \mathrm{WIB}$ & 2 minute \\
\hline
\end{tabular}

2. The begining of praying schedule for Batusangkar

In the second section table is found the data latitude $S$ is 0.5 , the correction is +18, m. 0.5 is to be completed to 1 .

a) Subuh time

The first section table (table 22 February) is obtained the subuh time on latitude S 1 is 04.51 . Then it is added with the correction 18 , so the subuh time is $04.51+00.18=05.09$ west Indonesian time zone (WIB).

b) Zuhur time

The first section table (table 22 February) is obtained the zuhur time on latitude $\mathrm{S} 1$ is 12.14 . Then it is added with the correction 18 , so the zuhur time is $12.14+00.18=12.32$ west Indonesian time zone (WIB).

c) Ashar time 
The first section table (table 22 February) is obtained the ashar time on latitude S 1 is 15.29 . Then it is added with the correction 18 , so the ashar time is $15.29+00.18=15.47$ west Indonesian time zone (WIB).

d) Magrib time

The first section table (table 22 February) is obtained the maghrib time on latitude $S 1$ is 18.18 . Then it is added with the correction 18 , so the maghrib time is $18.18+00.18=18.36$ west Indonesian time zone (WIB).

e) Isya time

The first section table (table 22 February) is obtained the isya time on latitude S 1 is 19.28 . Then it is added with the correction 18 , so the isya time is $19.28+$ $00.18=19.46$ west Indonesian time zone (WIB).

The result of these two hisab methods can be summarized to this following table:

Table 2

The begining of praying schedule in Batusangkar

\begin{tabular}{|l|l|l|l|}
\hline Shalat/Praying & Sa'adudin's Hisab & Contemporer Hisab & Difference \\
\hline Subuh & 05.09 WIB & $05.11 \mathrm{WIB}$ & 2 minutes \\
\hline Zuhur & $12.32 \mathrm{WIB}$ & $12.33 \mathrm{WIB}$ & 1 minute \\
\hline Ashar & $15.47 \mathrm{WIB}$ & $15.49 \mathrm{WIB}$ & 2 minutes \\
\hline Magrib & $18.36 \mathrm{WIB}$ & $18.37 \mathrm{WIB}$ & 1 minute \\
\hline Isya & $19.46 \mathrm{WIB}$ & $19.47 \mathrm{IB}$ & 1 minute \\
\hline
\end{tabular}

3. The begining of praying schedul in Jambi

In the second section table is founded the data of latitude $\mathrm{S}$ is 1,6 LS, correction +6 m.1, 6 and to be completed to 2

a) Subuh time

The first section table (table 22 February) is obtained the subuh time on latitude S 2 is 04.51 . Then it is added with the correction 6 , so the subuh time is $04.51+00.06=04.57$. west Indonesian time zone (WIB).

b) Zuhur time

The first section table (table 22 February) is obtained the zuhur time on latitude S 2 is 12.14 . Then it is added with the correction 6 , so the zuhur time is $12.14+00.06=12.20$. west Indonesian time zone $(\mathrm{WIB})$. 
c) Ashar time

The first section table (table 22 February) is obtained the ashar time on latitude S 2 is 15.28 . Then it is added with the correction 6 , so the ashar time is $15.28+00.06=15.34$. west Indonesian time zone $(\mathrm{WIB})$.

d) Magrib time

The first section table (table 22 February) is obtained the magrib time on latitude S 2 is 18.19 . Then it is added with the correction 6 , so the magrib time is $18.19+00.06=18.25$. west Indonesian time zone $(\mathrm{WIB})$.

e) Isya time

The first section table (table 22 February) is obtained the isya time on latitude S 2 is 19.28 . Then it is added with the correction 6 , so the magrib time is $19.28+$ $00.06=19.34$. west Indonesian time zone (WIB).

The result of these two hisab methods can be summarized to this following table:

Table 3

The begining of praying schedule in Jambi

\begin{tabular}{|l|l|l|l|}
\hline Shalat/Praying & Sa'adudin's Hisab & $\begin{array}{l}\text { Contemporer } \\
\text { Hisab }\end{array}$ & Difference \\
\hline Subuh & $04.57 \mathrm{WIB}$ & $04.58 \mathrm{WIB}$ & 1 minute \\
\hline Zuhur & $12.21 \mathrm{WIB}$ & $12.20 \mathrm{WIB}$ & 1 minute \\
\hline Ashar & $15.36 \mathrm{WIB}$ & $16.34 \mathrm{WIB}$ & 2 minutes \\
\hline Magrib & $18.26 \mathrm{WIB}$ & $18.25 \mathrm{WIB}$ & 1 minute \\
\hline Isya & $19.35 \mathrm{WIB}$ & $19.34 \mathrm{WIB}$ & 1 minute \\
\hline
\end{tabular}

The results of those two results of the hisab data, it can be conluded that Sa'aduddin Djambek's hisab method and contemporer hisab has little diferences about 1 to 2 minutes in determining the begining of praying schedule in the two cities. Nevertheless, there is a similarity in Ashar time in Aceh at 16.12 west Indonesian time zone. Despite, the data resources are different but the results are almost equal, even there is a similarity.

Each methods use ikhtiyat which is around 0.5 minute to 2 minutes. Ikhtiyat is urgently needed for Sa'aduddin Djambek's method. This is in line to his argument which use ikhtiyat as important role to avoid doing pray at inapropriate time.

From those two hisab methods, there are some differences in determining the begining of praying schedule in Indonesia. Author analyzes that those differences 
caused by methods, formula, and data which is used by those two methods. Notwithstanding, these difference results are not really significant, but it is only 1 or 2 minutes. The result of Sa'aduddin Djambek's method sometimes sooner or later compares to contemporary hisab. Hence, Sa'aduddin Djambek's hisab method and contemporary hisab which is use Ephimeris data are nearly equal in determining the begining of praying schedule in Indonesia.

\section{Conclusion}

In the last analysist, we can conclude that the differences of the result of all the time hisab with contemporer hisab is approximately 1 to 2 minutes. Moreover, all the time praying schedule is sometimes sooner or later instead of praying schedule calculated by contemporer hisab formula.

\section{E. Bibliography}

al-Asqalany, Alhafidz Imam Ibnu Hajar. Bhulughul Maram Min Addilatil Ahkam (CD Room), no hadis, 163.

Badan Hisab Rukyat Depag, Almanak Hisab Rukyat, Jakarta: Proyek Pembinaan Badan Peradilan Agama Islam

Djambek, Sa'aduddin. Arah Qiblat dan Cara Menghitungnya dengan Jalan Ilmu Ukur Segitiga, Jakarta: Tintamas, 1956.

Djambek, Sa'aduddin. Almanak Djamaliyah,Jakarta: Tintamas, 1953.

Djambek, Sa'adoeddin. Pedoman waktu Shalat sepanjang Masa, Jakarta: Bulan Bintang, 1974.

Hambali, Slamet. Ilmu Falak I ( Penentuan Awal Waktu Shalat dan Arah Kiblat Seluruh Dunia, Semarang: Program Pascasarjana IAIN Walisongo Semarang, 2011.

Izuddin, Ahmad. Ilmu Falak Praktis, Semarang: PT.Pustaka Rizki Putra, 2012

Jamil, A. Ilmu Falak Teori dan Aplikasi, Jakarta: Amzah, 2009.

Karim, Abdul dan M. Rifa Jamaluddin Nasir. Mengenal Ilmu Falak teori dan Implementasi, Yogyakarta: Qudsi Media, 2012.

Khazim, Muhyiddin. Kamus-kamus Ilmu Falak,Jogjakarta: Buana Pustaka, cet ke-I, 2005.

Murtadho, Moh. Ilmu Falak Praktis, Malang: UIN Malang Press, 2008.

Nur, Nurmal, Teknologi Hisab-Rukyat untuk Menentukan Arah Kiblat Awal Waktu Shalat Awal Bulan Qamariah,Padang: IAIN IB Padang.

Rahmi, Nailur. Ilmu Falak, Batusangkar: STAIN Batusangkar Pres, 2008.

Sabiq, Sayyid. Fiqh Sunnah, penejermah Khairul Amru Harahab dkk. 
Supriatna, Encup. Hisab Rukyat dan Aplikasinya, Bandung: Refika Aditama, 2007

Tokoh-Tokoh Falak di Indonesia: Saadoe'ddin Djambek http://bimasislam.depag.go.id.

Wardan, KR. Muhamad. Kitab Ilmu Falak dan Hisab, Jogjakarta: Soft Copy. 